\title{
Circuit
}

Musiques contemporaines

\section{Symphonie du millénaire : The Sacred in the Profane}

\section{Jonathan Goldman}

Volume 11, numéro 3, 2001

\section{Perceptions}

URI : https://id.erudit.org/iderudit/004670ar

DOI : https://doi.org/10.7202/004670ar

Aller au sommaire du numéro

Éditeur(s)

Les Presses de l'Université de Montréal

ISSN

1183-1693 (imprimé)

1488-9692 (numérique)

Découvrir la revue

Citer cet article

Goldman, J. (2001). Symphonie du millénaire : The Sacred in the Profane.

Circuit, 11(3), 33-38. https://doi.org/10.7202/004670ar
Résumé de l'article

Dans cet article, Jonathan Goldman propose quelques observations personnelles au sujet de la Symphonie du millénaire, tout en tentant de cerner sa signification culturelle. Muni de la partition et d'un enregistrement, l'auteur tente une analyse de l'oeuvre qui rejette la distinction entre le sacré et le profane, entre le religieux et le laïc, et en fait un « objet culturel » d'une ampleur considérable.
Ce document est protégé par la loi sur le droit d'auteur. L'utilisation des services d’Érudit (y compris la reproduction) est assujettie à sa politique d'utilisation que vous pouvez consulter en ligne.

https://apropos.erudit.org/fr/usagers/politique-dutilisation/ 


\title{
Symphonie du millénaire : The Sacred in the Profane
}

\author{
Jonathan Goldman
}

It is said that psychiatrists in Israel are trained to deal with a condition which is termed "Messiah Complex". This is a psychological disorder in which afflicted persons become convinced that they are the Messiah. When in Jerusalem, an individual suffering from this disorder, if not apprehended by a team of security guards on duty to protect against just such an occurrence, will attempt to ride onto the Temple Mount through the Dung Gate mounted bare-back on a donkey, in fulfillment of the Old Testament prophecy of redemption.

One does not need psychological training to understand that the weight of religion and history can adversely affect certain frail dispositions. The great JudeoChristian myths of Redemption, Temple, Apocalypse and Messiah can be, in certain cases, extremely burdensome, especially when coupled with an ingrained feeling of persecution.

Montreal, a kind of Jerusalem of the North, must also come to terms with a similar social predicament, a kind of collective Messiah complex. Besides having a mountain at its center, it was apparently founded in response to a mystico-religious vision. Its first official recognition was the decree of a clergyman, when on Sunday May 18, 1642, the Jesuit Père Barthélémy Vimont led a mass inaugurating the new settlement. Consequently, Montreal, or Ville-Marie, as it was then called, has always been in the shadow of the Temple Mount, and has always had a natural inclination towards all things redemptive, apocalyptic, messianic and monumental. This is at times in striking contrast with the rest of Canada, which rarely feels this pressing burden of history, and is little inclined towards displays of apocalyptic fervor. This phenomenon can have the benefit of imbuing artistic projects conceived in this city with a sense of urgency, of telos, which shows every sign of being an infiltration of secular space by the religious.

If the Symphonie du millénaire is unique, it is also one element in a series of large-scale monumental events staged in Montreal, which straddle the religious and secular spheres. Its logical ancestor is the late André Prévost's monumental statement in Terre des hommes, whose double orchestra and triple choir inaugu- 
rated the 1967 World Exposition. It is difficult to imagine events of this magnitude in other Canadian cities, and particularly not in its traditional rival, Toronto. One is tempted to say that Toronto lacks a Royal Mount at its core...

I will attempt, in this short paper, to convey some personal impressions of the Symphonie du millénaire. Being armed with a recording and a score, but not having participated in the organization or the conception of the work, I will try to give an impressionistic account of an event that, with its 40,000 spectators, is unprecedented in Contemporary Music, and without doubt attests to the health of musical life in Montreal, and, pourquoi pas?, a healthy relationship with its audience.

Impressions. An enormous orchestral mass. The opening "appels" of the Symphonie are a straightforward enunciation of the notes of the Veni Creator cantus firmus, punctuated by percussive interlocutions of bells. The opening tutti, in all its sumptuousness, gives an idea of the sheer "perversity" of such a huge orchestra contingent. Even if our ears (still in need of Schaferian Ear-cleaning) are polluted from having heard the huge layered sounds possible through sound synthesis, and ubiquitously employed in commercial music, the sound of a thousand-odd performers playing in unison is still a striking event from a purely acoustic point of view. If I used the word "perversity" in this context, it is because I am reminded of an article by Pierre Boulez on Berlioz's orchestration, in which he wryly juxtaposes Berlioz and ... the Marquis de Sade. He refers to Berlioz's Traité d'orchestration, in which he compiles a catalogue of instrumental combinations, which included certain orchestral mixtures which, because of logistic and economic constraints, could never be realized. Boulez compares this with Sade, who, at the end of 120 Days of Sodome, "draws up a catalogue of perversions still to be described". For his part, Berlioz's orchestral "perversions" included:

The combination in a large orchestra of 30 harps with the entire mass of strings play ing pizzicato, thus forming, in their ensemble, another gigantic harp with 934 strings, for graceful, brilliant, voluptuous accents throughout the entire range of nuances;

The combination of the 30 pianos with the 6 glockenspiels, the 12 pairs of antique cymbals, the 6 triangles (which, like the cymbals, could be tuned in different keys), and the 4 Turkish crescents, making up a metallic percussion orchestra, for joyful and brilliant accents in the mezzo-forte nuance.

(Boulez, 1986, p. 216.)

As we can see, Berlioz had the millenary spirit avant la lettre, and it seems to me that his spirit, not to mention Sade's, were evoked at St. Joseph's Oratory on June 3. Indeed, in a way, this mass of sound, requiring such a massive ensemble, had a curious effect of summarizing as well as repudiating the entire twentieth century at its close. For, as we know, the Wagnerian-Berliozian orchestra, with its tendency towards sumptuous expansion, was a typically nineteenth-century cipher of progress. A late example of this tendency, Mahler's Symphony no. 8, or Symphony of a thousand, written seven years into the twentieth century, is a kind 
of post-script to this tradition. Probably not coincidentally, this huge choral work, like the Symphonie du millénaire, also sets the Veni Creator theme in its first part.

In contrast to this tradition, the twentieth century, if it is possible to encapsulate the musical style of such a diverse period, is characterized by a paring down, by a tendency towards "soloism", i.e., one instrument per part, the contrapuntal effect over harmonic luxuriousness, a chamber music æesthetic even in the composition of orchestral works. Or at least this is what we are taught!

If this is so, the Symphonie du millénaire possesses some features typical of nineteenth-century late romanticism. Also romantic, or pre-modern, in the conception of the Symphonie du millénaire is the encyclopedic nature of the work: listening to it, the score in hand, one feels that the piece is a highly refined compendium of the compositional languages of the twentieth century. We find time-chart notation, improvisational parts, micropolyphony, as well as impressionistic and electroacoustic sections. One area of $20^{\text {th }}$ century exploration that is perhaps underrepresented, although this perhaps has to do with the specific character of composition in Quebec, is microtonal composition, or the so-called just-intonation school. This, however, does nothing to contradict the impression of omnivorousness. So thorough is the Symphonie, that we even have allusions to early music or folklore in the section written for the SMAM' by Sean Ferguson. However, one senses a contrast with respect to another piece which is also a kind of compendium of the $20^{\text {th }}$ century, Berio's Symphonia (1968-69), which is said to contain passages in which Stravinsky and Schönberg walk side by side. In the Symphonie du millénaire, although this is entirely unverifiable, the ironymeter not having been invented, one does not sense the kind of postmodern irony that one associates with Berio's work; nor does one have the impression of a kind of romantic aufhebung, a kind of sublimation of the language of the century at its close. The overall impression of the work is one of a brilliant and extremely virtuosically written presentation of the compositional language at its present state. Whereas the message of the postmodernistic version of the compendium, and especially of the Symphonia, is one of repudiation: after the modernist, teleological view of history is disavowed, all of history's phases coexist in purposeless playfulness, in pure game. In the Symphonie du millénaire, we discern a kind of more serious pursuit: a synthesis of all present languages, in pursuit of a kind of language of redemption.

Also, if I characterized the encyclopedic character of the Symphonie du millénaire as being opposed to the kind of playful irony which one associates with the ironic smile of Postmodernism's homo ludens, that is not to say that it is a work of humourless earnestness: indeed, on occasion, playful wit, always a welcome respite from the apocalypse, can be seen: for example, in the contribution of a composer who has been profoundly inspired by Postmodernism, Jean Lesage, who wrote an organ transition entitled A Weekend in Purgatory.

A sacred work then? According to Hannah Arendt, the categories "secular" and "religious", or "sacred" and "profane" are not useful in the analysis of modern his- 
tory, since in a secularized society, religious tendencies, rather than receding into nothingness, infuse the secular world. We should therefore not be surprised that a secular work, composed in secular Quebec bears certain marks of the sacred.

If we analyze religion in structuralist terms, and borrow the terminology of Claude Levi-Strauss, we see that much of the practice of religion, and Christianity in particular, aims at transcending history; religions aim at a kind of synchronic jump in which the initial event of revelation, upon which every religion is founded, is available through immediate experience, without the gulf of diachronic history to distance it. The Symphonie du millénaire is then religious inasmuch as it uses this assumption in order to bridge a historical gulf, by denying the break with tradition, which for most thinkers of the beginning of this century is the defining characteristic of the modern era. The orchestra gets bigger, it uses electrical amplification to achieve an even more awesome effect; it believes in the possibility of this long 90 minute work, held together by the glue of the notes of the Veni Creator hymn (Schönbergian romantic utopianism!); its goal is awe, terror, redemption, catharsis. Without specifically using the language of musical romanticism, the Symphonie du millénaire evokes all the noble goals of that Beethovenian century, the very goals that were notoriously inverted by Thomas Mann's anti-romantic antihero, the composer Adrian Leverkühn, in the novel Doctor Faustus. If I allow myself to heap allusion upon allusion, this attempt to have art speak with the authority of antiquity while nevertheless using modern idiom, that is, without resorting to $\mathrm{Neo}$ classicism, is reminiscent of Gaudi's unfinished Sagrada Familia church in Barcelona. The language of modern architecture is used there in the service of the Church as if nothing had changed since the medieval time of masons and guilds.

I alluded above to the use of the Veni Creator theme as "Schönbergian Utopianism"; this may be so; however, we would expect nothing less from a work which hopes to be a kind of resumé of the millenium (or of the century). This tendency towards unification through a global serial structure is what Pierre Boulez calls hyper-thématisme, and it remains a prevailing myth of classical music up to and including the Post-War period. If I call it a myth, it is not to denigrate it, nor to question its justification in psychoacoustic terms, but to emphasize its existence as a psychological object.

The concept of Hyper-thématisme is outlined in Boulez's essay "Athématisme, identité et variation" (in Boulez, 1989, pp. 239-290). Hyper-thématisme is a feature of Western music as it reaches its maturity, as well as a compositional process, in which a musical work is entirely deduced from the intervals of one primordial theme or cell, which guarantees its structural unity. This concept, cornerstone musical structuralism, is the prevailing myth of the modernist in music, and therefore, unquestionably deserves the central position which it occupies in the Symphonie.

However, it seems to me that the success of the work in the public eye lies not in the serial underpinning provided by the Veni Creator theme, in this consistent 
hyperthematicism which unifies the piece, but rather in its successful use of the play of oppositions:

$\begin{array}{ll}\text { heaven } & \text { hell } \\ \text { redemption / } & \text { despair } \\ \text { consonance / } & \text { dissonance } \\ \text { diatonicism / } & \text { chromaticism } \\ \text { tonality } & \text { atonality }\end{array}$

This oppositional trope is used to effective dramatic end, in a way reminiscent of Wozzeck: these are oppositions which the audience understands, that have the familiarity of the language of film music, and their effective use almost belies the modernist Schönbergian or Boulezian attempt at eradicating the distinction between consonance and dissonance, which is the true meaning of Schönberg's "emancipation of the dissonance".

In closing, it would perhaps be instructive to apply Adorno's remarks on Moses und Aron, without doubt one of the few masterpieces of modernist sacred music, as contradictory as this concept may seem, to the Symphonie du millénaire.

But [Schönberg] does strive for a balance between the pure musical development and the desire for monumentality, much as Wagner had done. He too extended his critique of the musical theatre to the bounds of what was possible in his day. But at the same time he wanted the larger-than-life as evidence of the sacred. ...Moses und Aron is traditional in the sense that it follows the methods of Wagnerian dramaturgy without a hiatus.

(Adorno, 1994, p.239.)

Similar to the case at hand, we have in this passage the desire to erase the 'hiatus' separating Wagner from we moderns, and the desire to find a language of monumentality. We can paraphrase Adorno's remarks on Schönberg and his Moses und Aron and apply it to the Symphonie du millénaire:

It is inspiring to see with what overwhelming power Schönberg has succeeded in overcoming the recalcitrant nature of his material in order to accomplish this at the very moment when such pathos had become an anachronism.

(Adorno, 1994, p. 240.)

In a similar way, the Symphonie du millénaire makes use of these anachronistic themes to its advantage, and to its credit: it rekindles the outmoded ideas that music is a form of humanism, that it can speak of redemption and of apocalypse. It manages to say, in an effective way, what it is no longer possible to say from atop a mountain crowned by an electrified cross, place-holder of a barely remembered absent sacred past. It is this praise, as applied to the 19 composers of the Symphonie du millénaire, that is most befitting for an event which was surely one of the most noteworthy events in the world to mark the millennium. 
ADORNO, T. (1994) Quasi Una Fantasia: Writings on Music, trans. by Rodney

Livingstone, New York, Verso, 336 p.

BOULEZ, P. (1986) Orientations: Collected Writings, ed. by Jean-Jacques Nattiez, trans. by Martin Cooper, Cambridge Mass, Harvard University Press, $541 \mathrm{p}$

BOULEZ, P. (1989) Jalons (Pour une Décennie), compiled by Jean-Jacques Nattiez, Paris, Christian Bourgois Éditeur, $452 \mathrm{p}$. 